Clemson University

TigerPrints

$12-2016$

\title{
A Formative Experiment to Align Middle-School History Instruction with Literacy Goals
}

Jamie Colwell

David Reinking

Follow this and additional works at: https://tigerprints.clemson.edu/eugene_pubs

Part of the Education Commons 


\title{
A Formative Experiment to Align Middle- School History Instruction with Literacy Goals
}

\author{
JAMIE COLWELL \\ Old Dominion University \\ DAVID REINKING \\ Clemson University
}

Background/Context: Recent curricular trends based on new standards emphasize the centrality of reading and studying texts in history instruction. That trend suggests a closer alignment between middle-school history instruction and goals for developing literacy. Yet potential obstacles identified in the literature, particularly a teacher's stance toward teaching history, imply challenges to instantiating that alignment. Relatively little research has addressed how relevant conceptual positions such as disciplinary literacy might be realized in authentic practice.

Purpose/Objective: The objective was to investigate how middle-school history instruction could be transformed to align with the literacy goals addressed in new curricular standards and to better understand within a typical instructional context the pedagogical influences and outcomes associated with such a transformation. The intent was to lay the groundwork for an emerging pedagogical theory that could guide efforts to align history instruction and literacy goals.

Intervention/Program/Practice: The researchers and the teacher collaboratively planned the instructional intervention that entailed three essential elements: (a) reading primary and secondary historical texts, (b) scaffolding strategies for reading such texts, and (c) writing blog reflections about readings. The teacher implemented the intervention in five topical history units taught during 10 consecutive weeks.

Research Design: We employed a formative experiment to determine what factors enhanced or inhibited the intervention's success in achieving its aim, how it could be modified in light of those factors, what unanticipated outcomes were observed, and the extent to which the teaching and learning environment was transformed.

Data Collection and Analysis: We collected qualitative data from multiple sources. During the intervention, we used an embedded case study to frame data collection and analysis. We conducted a retrospective analysis after the intervention phase in order to generate pedagogical assertions as a first step in establishing an emergent pedagogical theory.

Teachers College Record Volume 118, 120302, December 2016, 42 pages

Copyright $@$ by Teachers College, Columbia University

0161-4681 
Conclusions/Recommendations: Three key assertions emerged that mediated the teacher's efforts to align her history instruction with literacy goals: (a) the influence of her beliefs grounded in her previous, imagined, and enacted practice; (b) blogging as a motivational catalyst; and (c) instructional enhancements that occurred when she observed the intervention's positive effects on achieving her pedagogical goals for students. These assertions comprise an emerging theory of how history instruction might be aligned with literacy goals and, as such, inform the literature on disciplinary literacy and how it might be achieved in authentic practice.

Although politically unstable and increasingly contested, the Common Core State Standards (CCSS; National Governors Association \& Council of Chief State School Officers, 2010) are likely to have considerable influence on curriculum, instruction, and assessment for the foreseeable future (Coleman, 2011; Hinchman \& Moore, 2013). One of the distinctive features of the CCSS at the middle-school level is the inclusion of standards for instruction in history/social studies (hereafter "history") in overarching standards for the language arts. As some have argued, that positioning highlights the centrality of reading and studying texts in history instruction and suggests a closer alignment between middle-school history instruction and goals for developing literacy (Nokes, 2011).

However, the CCSS represent only the latest impetus for a closer alignment of history instruction and goals for literacy, given the central role of textual information in studying history. For example, Wineberg's seminal work (1991) analyzing how historians read source texts has been frequently cited as a basis for engaging students in reading texts as historians do (e.g., Nokes, Dole, \& Hacker, 2007; Reisman, 2012; Stahl, Hynd, Britton, McNish, \& Bosquet, 1996). Further, the National Council for the Social Studies (NCSS) recently published a College, Career, and Civic Life (C3) framework to provide guidance to states in revising existing social studies standards to increase rigor of curriculum (NCSS, 2013). This framework promotes reading and analysis of historical documents to provide curricular guidelines for history teachers in order to support students in "understanding and evaluating change and continuity over time, and making appropriate use of historical evidence in answering questions and developing arguments about the past" (p. 45). Such guidelines encourage literacy in the analysis and understanding of historical evidence from a disciplinary perspective.

Paralleling these curricular trends, scholars interested in adolescent literacy have proposed the concept of disciplinary literacy as a needed (Lee \& Spratley, 2010; Shanahan \& Shanahan, 2008, 2012), promising (Moje, 2008), and viable (Draper, 2008; Draper, Broomhead, Jensen, \& Siebert, 2010) framework for integrating literacy skills, strategies, and dispositions into the teaching of academic subjects. Although only one of multiple concepts that have been suggested as the goal of history and other content area 
instruction, the core principle of disciplinary literacy is the proposition that literacy is manifested uniquely in each of the major academic disciplines, such as history, science, and mathematics. It assumes that teachers of these subjects are in a good position to develop academic literacy while teaching their respective disciplines (Moje, 2008; Shanahan \& Shanahan, 2008, 2012) and that these teachers should consider it their responsibility to do so. Further, history is a subject frequently used to illustrate disciplinary literacy (De La Paz, 2005; Girard \& Harris, 2012; Nokes, 2010, 2011).

Nonetheless, there are challenges to aligning history instruction with literacy goals. For example, many history teachers do not routinely frame instruction as engaging their students in the process of the discipline, which includes a critical stance in reading primary and secondary texts that are often linguistically and structurally complex (Bain, 2006, 2012). The literature also suggests that integrating the concept of disciplinary literacy into history instruction may be time-consuming for teachers and, at least initially, difficult for students to engage in successfully (Bain, 2005; VanSledright, 2002a). Particularly, students may lack or have underdeveloped conventional literacy skills to support these practices (Brozo, Moorman, Meyer, \& Stewart, 2013; Faggella-Luby, Graner, Deshler, \& Drew, 2012; Nokes, 2011). Further, teachers may not readily embrace new instructional goals and teaching practices, especially if they perceive that focusing on literacy moves them away from familiar routines, perspectives, and goals, which has been a longstanding concern in research on promoting content-area literacy (Alvermann \& Moore, 1991; O'Brien, Stewart, \& Moje, 1995). Although the literature on disciplinary literacy is well established (Moje, 2007), there is less research investigating the process of how history teachers might align their instruction with disciplinary perspectives to suit the needs of all learners, as well as the challenges they might face (Girard \& Harris, 2012).

\section{METHODOLOGICAL AND THEORETICAL STANCE}

To better understand these challenges and how they might be addressed in practice, we conducted a formative experiment in an eighth-grade history class to determine how one teacher's history instruction could be aligned with literacy goals. We collaborated with Ms. Wells (all names are pseudonyms), the teacher, to engage her students in activities related to analyzing primary and secondary sources and, in response to those sources, in writing personal blogs that would be shared with and responded to by pre-service social studies teachers. The intervention aimed to promote a closer alignment between history instruction and literacy goals, and it provided an opportunity to investigate how that might occur in a typical 
middle-school history class. Consistent with an established methodological frame for conducting formative experiments (Reinking \& Bradley, 2008), we gathered data to determine what factors enhanced or inhibited the intervention's success in achieving its aim, how it could be modified in light of those factors, what unanticipated outcomes were observed, and the extent to which the teaching and learning environment was transformed. We aimed not only to determine how the intervention might achieve its goals, but also to develop deeper pedagogical insights. That is, our purpose was to generate what Cobb, Confrey, diSessa, Lehrer, and Schauble (2003) refer to as emergent, domain-specific instructional theory, not just to "tinker toward perfection" (p. 9).

Our conceptual frame was disciplinary literacy. However, in our initial interactions with Ms. Wells, who was enthusiastically committed to the project and its goals, we discovered that disciplinary literacy did not fully capture her view of how she might better align her instruction with literacy goals. In interviews before the instructional intervention, she clearly indicated a familiarity with the term disciplinary literacy and its conceptual underpinnings, although, interestingly, she preferred the term critical thinking. She also expressed a commitment to several of the fundamental goals associated with disciplinary literacy in history instruction, such as analyzing relationships and making comparisons among historical texts (primary and secondary sources), understanding author bias and the purpose of a text, and using textual information to support analysis of historical texts. However, these goals were inextricably entwined with her beliefs about and priorities for teaching history. For example, in an interview she expressed a commitment to "students considering the social implications of historical events and how those events may influence present society" (Interview, August 11, 2011), which is consistent with the work of educators who argue that history instruction should enable students to understand contemporary societal issues (e.g., Barton \& Levstik, 2004).

Thus, consistent with the stance of researchers conducting formative experiments (i.e., researchers following the lead of practitioners; see Reinking \& Bradley, 2008), our conception of disciplinary literacy in this study accommodated Ms. Wells's views, which, although consistent with disciplinary literacy, did not fully capture her stance. That stance extended to all instructional decisions, including any modifications to the intervention that our data suggested might be useful or beneficial. In that regard, we were not passive collaborators. Yet we consciously limited our involvement to following her lead or responding to her requests for our input. Taking that stance mitigates the influence of a researcher and enhances opportunities for obtaining insightful data (Colwell, Hunt-Barron, \& Reinking, 2013; Parker et al., 2013; Reinking \& Watkins, 2000). 


\section{RATIONALE AND EMPIRICAL SUPPORT}

There is considerable evidence that aligning history instruction with literacy goals is challenging for teachers and students. Teachers perceive pressure to cover a wide range of content and historical facts to prepare students for standardized testing (Hicks, 2005; Neumann, 2013). Further, they tend to rely on a sanctioned textbook as the primary and authoritative source of information about history and historical events (e.g., Paxton, 1999). Likewise, students typically rate history textbooks as more trustworthy than other academic texts (Rouet, Favart, Britt, \& Perfetti, 1997; Stahl \& Shanahan, 2004), even though they can contain inaccuracies and biases (Alridge, 2006). That stance may limit frames for teaching and learning when primary and secondary texts are introduced as sources for critical analysis.

VanSledright (2002a) identified another obstacle in his study of fifthgrade students engaging in structured practices of historical investigation. Although the students were capable of engaging in disciplinary practices, they often struggled to make evidence-based interpretations, sometimes substituting their own interpretations based on personal opinions. To integrate disciplinary literacy into a history class, students must be engaged in investigating and analyzing a wide range of high-quality texts (Fang \& Pace, 2013; VanSledright, 2002a, 2002b; Wineburg, 1991, 2001), which entails inquiry-based approaches to reading historical texts (Barton \& Levstik, 2004). For many teachers of adolescent students, and for the students themselves, inquiry-based approaches to reading complex historical texts may be an unfamiliar practice (Fang \& Pace, 2013). Further, it is reasonable to suppose that teachers who see their students struggling to contend with more difficult analytical approaches to texts may reject or retreat from instructional activities and from highlighting such approaches.

History teachers' beliefs mediate instruction (Cochran-Smith \& Zeichner, 2005). For example, a longstanding finding is that subjectarea teachers do not believe that literacy is their responsibility (O'Brien et al., 1995). That finding holds even if they realize that literacy-based strategies may be necessary for students' success in acquiring disciplinary learning (Faggella-Luby et al., 2012; Nokes, 2011). In social studies, for example, Van Hover and Yeager $(2003,2007)$ found that in-service teachers may struggle when instructional activities conflict with their beliefs, particularly their doubts about students' ability to investigate and to read critically in history.

Nonetheless, there is convincing evidence that these challenges need to be addressed. Studies of efforts to instantiate disciplinary literacy in 
history report increased critical analysis, which is increasingly expected as students advance to higher grade levels (Achugar \& Carpenter, 2012; De La Paz \& Felton, 2010; Girard \& Harris, 2012; Nokes et al., 2007). Further, it has been argued that disciplinary literacy promotes skills that extend beyond the particular discipline in which they are practiced and from which they might emerge (e.g., Moje, 2008). For example, reading texts like a historian means considering the source of relevant texts, an author's perspective and potential biases, the context in which a text is written, and corroborative evidence across texts (Barton \& Levstik, 2004; Beyer, 2008; Wineburg, 1991, 2001), all of which undergird effective democratic citizenship (see also NCSS Task Force on Revitalizing Citizenship Education, 2001). In that vein, Mosborg (2002; see also Botstein, 1991; Stahl \& Shanahan, 2004) argued that teaching and promoting the consideration of bias in historical texts would enable students to "recruit and use historical knowledge throughout their political and cultural lives" (p. 324).

However, few studies address instructional interventions aimed at promoting disciplinary literacy in history, particularly in middle grades (for exceptions see De La Paz, 2005; De La Paz and Felton, 2010; MonteoSano, De La Paz, \& Felton, 2014), thus providing little guidance about the means and processes for productively integrating the goals of disciplinary literacy into instruction. Existing studies focus on secondary or post-secondary students, which is potentially problematic because, for example, the CCSS demand attention to the critical analysis of texts beginning in the sixth grade. Some researchers have also argued that disciplinary literacy, absent more general strategy instruction, is untenable for many students (Brozo et al., 2013; Faggella-Luby et al., 2012). Indeed, Hynd-Shanahan (2013) and Brozo et al. (2013) noted the positive role that content-area literacy strategies might play in disciplinary instruction if modified to fit the specific objectives of a discipline and of a particular teacher.

Thus, the rationale for this formative experiment is grounded in the instructional imperatives of new and existing standards for history/ social studies; in the documented challenges to the transformation of teaching needed to align instruction with the CCSS, particularly in classrooms serving struggling readers and learners; and in the concept of disciplinary literacy and its presumed benefits for academic success and informed citizenship. Investigating how that goal can be achieved and the pedagogical theory that might be derived from doing so is important given the paucity of research on the means and processes for transforming instruction. 


\section{METHOD}

\section{PARTICIPANTS}

Ms. Wells, the teacher, had 13 years of teaching experience. Twice she had received district-level awards for excellence in teaching. She had taught exclusively at Townley Middle School, where this study was conducted. She had a bachelor's degree in secondary social studies education and a master's degree in education administration, although she had opted to remain a classroom teacher because of her enthusiasm for and commitment to working directly with students. A motivation for her to participate in this study was her interest in refocusing her instruction to incorporate recently revised state standards that aligned with the CCSS. She stated that she felt "underprepared to teach history using discipline-based instruction that required students to critically consider texts" (Interview, April 12, 2011).

Prior to the beginning of the study, we discussed with Ms. Wells the pedagogical goal of the intervention, its rationale, its essential elements, the unique aspects of formative experiments as an approach to education research, the minimum commitment of her time and involvement that would be necessary for a viable project, and the different levels of partnership she could choose to assume in working with us on the project (see Cole \& Knowles, 1993). We also discussed, in general, how she might decide to integrate the intervention into her instruction. We then scheduled several meetings to engage in more specific collaborative planning to determine how it might initially be integrated into her teaching. She decided to implement the intervention in one class of 25 eighth-grade students (13 girls and 12 boys; 13 White, 7 African American, 5 Hispanic) studying state history. The class represented diverse academic achievement as reflected in test scores and grades, although no students qualified for special education instruction. She also knew these students well, having taught all but five of them the previous year, and she noted that "many struggle with reading on grade level" (Interview, August 11, 2011).

\section{THE INTERVENTION}

In a formative experiment, an intervention is defined by its essential, defining elements that, if removed, would result in a different intervention (Colwell \& Reinking, 2013). Nonetheless, essential elements can be implemented in infinite ways to accommodate the conditions of a particular classroom and a teacher's preferences, as well as in response to data suggesting necessary or useful modifications. The instructional intervention investigated in this formative experiment comprised three essential elements, each of which is supported in the literature and is consistent with 
efforts to more closely connect history instruction and literacy goals: (a) reading primary and secondary text sources (Afflerbach \& VanSledright, 2001; Hynd, 1999); (b) explicit instructional activities to develop, encourage, and illustrate approaches to critically reading and analyzing historical texts (Barton, 1996; Guthrie \& Wigfield, 2000; Nokes, 2008; Nokes et al., 2007); and (c) responding to historical texts using Internet blogs (Bull, Hammond, \& Ferster, 2008; Hicks \& Doolittle, 2008; Martin \& Wineburg, 2008; Shoffner, 2007; Weiler, 2003).

The intervention occurred over 10 consecutive weeks. In our initial planning with Ms. Wells, she decided to implement the intervention within five sequential topical units of approximately two weeks each. She decided that for the first instructional unit, she would introduce students to blogging and to the logistics of using the blogs to communicate with their blogging partners (one pre-service teacher in a social studies methods course assigned to each student). We had arranged with a colleague to engage his students as blogging partners in that course; partners were matched arbitrarily. For blogging, we used My Big Campus, a closed-social network, because the school district had purchased a license to use it and because it was designed to be a closed, and therefore safe, networking site for students in K-12 schools. The middle-school students began by writing an initial blog entry introducing themselves, with their university partners responding in kind.

Ms. Wells also planned to incorporate primary and secondary sources into the first unit. She had used such sources previously because they were specified in the state standards, but, as she stated, "I used primary sources mainly to show students how documents looked in the past, rather than have them analyze a document" (Interview, August 11, 2011). Thus, she decided to incorporate several of the textual sources she had used previously into the units, although, at her request, we suggested a few for her consideration, which she then decided to use. The topics, focal history texts, and a schedule for introducing them are summarized in Table 1.

During our joint planning, Ms. Wells was enthusiastic about using activities that promoted a critical perspective in reading historical texts. She indicated that moving in that direction was consistent with a workshop she had recently attended that emphasized strategies and activities important to teaching the state standards in history. After discussing several possible approaches with us, she decided that Questioning the Author (QtA) (Beck \& McKeown, 2001; Beck, McKeown, Sandora, Kucan, \& Worth, 1996) was well suited to her instruction, although with some modification. QtA, a content-area literacy strategy, introduces students to the perspective that authors are fallible and may not always write in a manner that is clear and easy to comprehend, thus encouraging close reading of texts to question 
the author's meaning as an aid to comprehension. QtA has been found to encourage students' thinking about the author's role in shaping a text's content and presentation by having students engage in a series of specific queries as they read through texts (Beck \& McKeown, 2001; Beck et al., 1996). Additionally, she selected Beyer's (2008) instructional approach, which provides guidelines for thinking about social studies, to complement QtA and to promote a disciplinary stance toward reading.

Because these approaches rely on series of questions to guide students through reading, Ms. Wells selected three types of graphic organizers (see Appendix A for examples) to organize these questions, which she felt would structure students' thinking as they read. We refer to the graphic organizers as strategies hereafter, because they were developed to support students in reading historical texts and to develop independence in reading historical texts critically, which is a goal of strategy instruction in the content areas (Alvermann, Gillis, \& Phelps, 2012). She told us that she planned to introduce and use at least one type of graphic organizer during class activities with her students at least twice a week (using Beyer's, 2008b, suggestions for modeling and thinking aloud to structure introduction) to focus on the reading of historical texts, specifically to address the validity of sources, author bias, and intertextual connections. These planned activities were intended to comprise explicit instructional activities, which were an essential element of the intervention. Her subsequent

Table 1. Schedule, Topics, Texts, and Type of Source

\begin{tabular}{|c|c|c|}
\hline $\begin{array}{l}\text { Weeks } \\
\text { (Lessons) }\end{array}$ & Topical Units \& Supplementary Texts & Type of Source \\
\hline $\begin{array}{l}1 \& 2 \\
(1-4)\end{array}$ & $\begin{array}{l}\text { English Explorers in the Carolinas } \\
\text { Introductory blog posts to begin the blog project } \\
\text { King Charles II's } 1663 \text { charter of land to proprietors }\end{array}$ & Primary \\
\hline $\begin{array}{l}3 \& 44 \\
(5-8)\end{array}$ & $\begin{array}{l}\text { Colonial Women in the Carolinas } \\
\text { "Affra Harleston Coming"-excerpt from South Carolina } \\
\text { Women (Bodie, 1991) }\end{array}$ & Secondary \\
\hline $\begin{array}{l}5 \text { \& } 6 \\
(9-12)\end{array}$ & $\begin{array}{l}\text { Slavery in the South Carolina } \\
\text { "They Said I Was Worth } \$ 400 \text {-excerpt from Voices of South } \\
\text { Carolina Slave Children (Rhyne, 1999) } \\
\text { "The Stono Rebellion"-excerpt from The Thirteen Colonies: } \\
\text { South Carolina (Doherty \& Doherty, 2005) }\end{array}$ & $\begin{array}{l}\text { Primary } \\
\text { Secondary }\end{array}$ \\
\hline $\begin{array}{l}7 \& 8 \\
(13-16)\end{array}$ & $\begin{array}{l}\text { Plantation Life in South Carolina } \\
\text { "Eliza Lucas Pinckney"-excerpt from South Carolina Women } \\
\text { (Bodie, 1991) } \\
\text { "Daniel Axtell's Plantation"-excerpt from The Thirteen } \\
\text { Colonies: South Carolina (Dougherty \& Dougherty, 2005) } \\
\text { Letter from Governor William Bull to the Royal Council } \\
\text { regarding the Stono Rebellion (1739) }\end{array}$ & $\begin{array}{l}\text { Secondary } \\
\text { Secondary } \\
\text { Primary }\end{array}$ \\
\hline $\begin{array}{l}9 \& 10 \\
(17-20)\end{array}$ & $\begin{array}{l}\text { American Revolution in South Carolina } \\
\text { "The Battle at Stallions"-excerpt from Voices of the American } \\
\text { Revolution (Southern, 2009) }\end{array}$ & Primary \\
\hline $\begin{array}{l}11 \\
(21)\end{array}$ & $\begin{array}{l}\text { Post-intervention } \\
\text { Final blog posts to conclude the blog project }\end{array}$ & None \\
\hline
\end{tabular}


hesitation to implement these activities, the reasons for her hesitation, and how we were able to address it reveal central findings that are presented and discussed in the results section.

\section{INSTRUCTIONAL CONTEXT}

Before implementing an intervention, researchers conducting formative experiments seek a deep understanding of the instructional context (Reinking \& Bradley, 2008). Toward that end, we collected a variety of forms of data to better understand the context, visiting Townley School and the community in which it was located several times during the spring of the academic year preceding our work in Ms. Wells's classroom. We met with Townley's assistant principal to discuss the school and community, to acquire demographic data, and to establish our presence in the school while recording general impressions. We learned that Townley, one of four middle schools in a district of 5,600 students, enrolled 380 students. Although the district qualified for Title I funding to improve achievement, Townley was not a Title I school. The district served a rural community, with $40 \%$ of students from low-income families. Among Townley's students, $55 \%$ qualified for free or reduced-price lunch, and $73 \%$ had met state standards in the area of social studies; $59 \%$ of the students were White, 37\% were African American, and 4\% were Hispanic.

During the third week of the following school year, our focus shifted to becoming thoroughly acquainted with Ms. Wells's teaching and her classroom. We interviewed Ms. Wells about her aims, her goals, the objectives guiding her teaching in general and particularly in relation to teaching history, and how she viewed aspects of literacy in her teaching. For five consecutive days, we observed and recorded our observations, supplemented by video recordings, in each of her classes throughout the school day. We noted how Ms. Wells interacted with students, how students interacted with one another, the instructional and social climate of the classroom, instructional and other routines, approaches to history instruction, and so forth. We confirmed these initial impressions with Ms. Wells in the 10 weeks of the intervention that followed. We also confirmed our observations with Ms. Wells to ascertain that what we observed and recorded were typical routines in her classroom. The length of this study limited the time we were allowed to establish context, but we took additional measures by communicating with Ms. Wells to ensure that our observations were accurate.

A typical class period began with a prompt related to course content, to which students responded in their journals, or with a request to write a few sentences summarizing what they had learned during recent classes. Ms. 
Wells might then present some content using the interactive whiteboard, with students taking notes, followed by individual work on assignments, workbook sheets, or projects while she circulated among students asking questions and offering help. We noted that she had good rapport with her students; their comments and behaviors suggested that they liked and respected her. We did not observe her using any small-group work; when asked, she explained that the physical limitations of the room were not conducive to that approach and that it allowed students to veer off topic. However, she indicated that she was not opposed to small-group work and sometimes had students work in pairs. Neither did we observe instruction consistent with using inquiry methods or disciplinary approaches to history; instead, instruction was typically teacher-centered and lecture-based. Students were evaluated mainly on the basis of a folder each of them kept containing journal entries, tests, assignments, and projects.

\section{DATA COLLECTION AND ANALYSIS}

During the intervention, we used an embedded case study (Yin, 2009) to frame data collection and analysis. Case-study research focuses on an issue or process investigated through one or more cases within a bounded system (Creswell, 2007; Yin, 2009), which in the present study was the intervention phase. However, cases may contain multiple units of interest that inform the case, often suggesting the creation of embedded units of analysis within the case study to organize and understand the overall case (Yin, 2009). In this study, the five topical instructional units demarcated the embedded units aimed specifically at determining factors that enhanced or inhibited the intervention's effectiveness in achieving the pedagogical goals and at informing consequent modifications of the intervention. That is, data collection and analysis within each topical unit informed modifications to the next unit, iteratively across the five units. Each embedded case occurred during approximately two weeks, consisting of four class periods during which the intervention was implemented and observed.

Data included field notes taken during 27 classroom observations; participant observations (Yin, 2009); video recordings of lessons; informal interviews and debriefings with Ms. Wells, conducted once a week during the intervention; three semi-structured (pre-, mid-, and post-study) interviews with Ms. Wells; semi-structured interviews and focus-group discussions with students; and students' blog posts.

During the intervention phase, iterative cycles of data collection and analysis guided formative modification of the intervention (McKenney, Nieveen, \& van den Akker, 2006; McKenney \& Reeves, 2012), based on 
themes that emerged from data analysis during each cycle. Our analysis utilized constant comparative methods (Glaser \& Strauss, 1967) through a process of open and axial coding to relate concepts and categories found within field notes, video, and interview data, which were then used to develop themes that emerged from the data (Corbin \& Strauss, 2008). We used open coding to segment data into derived codes; axial coding allowed us to connect codes and to create categories across data (Corbin \& Strauss, 2008). These categories informed the identification of themes used to determine modifications to the intervention. Table 2 provides a sample of coding leading to categories that guided modifications during the intervention.

\section{Table 2. Examples of Open and Axial Coding Leading to Modification}

\begin{tabular}{lll}
\hline \multicolumn{1}{c}{ Example } & \multicolumn{1}{c}{ Code } & \multicolumn{1}{c}{ Category } \\
\hline $\begin{array}{l}\text { Wells briefly introduces salamander project and gives } \\
\text { students 20 minutes to look through past students' finished } \\
\text { projects as guides (field notes, September 19). }\end{array}$ & $\begin{array}{l}\text { Teacher us- } \\
\text { ing models }\end{array}$ & $\begin{array}{l}\text { Preference } \\
\text { of model- } \\
\text { based } \\
\text { Students are creating advertisement for English to come } \\
\text { to Carolina. Wells uses past students' finished projects as } \\
\text { guides (field notes, September 22). }\end{array}$ \\
$\begin{array}{l}\text { "This is one thing [i.e., reading comprehension] that con- } \\
\text { cerns me. I have multiple students who struggle with read- } \\
\text { ing and I worry that this project may be too hard for them. }\end{array}$ & $\begin{array}{l}\text { Teacher } \\
\text { resistance } \\
\text { to strategy } \\
\text { I think it might be good for them, but I'm worried that the } \\
\text { strategies are going to overwhelm them, like the primary }\end{array}$ & $\begin{array}{l}\text { Discomfort } \\
\text { Value of } \\
\text { source activity. They just seemed so discouraged, }\end{array}$ \\
$\begin{array}{l}\text { sthem } \\
\text { them to enjoy studying history" (Ms. Wells, informal inter- } \\
\text { view, September 19). }\end{array}$ & $\begin{array}{l}\text { student } \\
\text { appeal in } \\
\text { instruction }\end{array}$ & \\
\hline
\end{tabular}

After the intervention, we conducted a retrospective analysis (Gravemeijer \& Cobb, 2006), which is a post-intervention, holistic analysis of all the data collected. A retrospective analysis synthesizes across data initially focused on guiding modifications during the intervention. The aim is to develop emerging domain-specific (in the present case history instruction) instructional theory (Cobb et al., 2003). The results of that analysis are presented subsequently in the results section as pedagogical assertions. Following Gravemeijer and Cobb (2006), we conducted the retrospective analysis using a variation of constant comparative methods (see Duffy, 2001). Specifically, we analyzed data chronologically to determine emerging themes (pedagogical assertions) using the following sequence: (a) creating a descriptive account considering all the data, (b) categorizing data to construct categories across data, (c) constructing tables and charts summarizing data within and across categories and noting discrepancies (i.e., triangulation), (d) comparing and contrasting established 
codes to determine overall categories, (e) determining themes from overall categories, and (f) revisiting and discussing themes and findings to increase validity. Table 3 shows a representative example of this process.

Table 3. Example of Coding in the Retrospective Analysis

\begin{tabular}{|c|c|c|}
\hline Data Summary Excerpt & Code & Category/Theme \\
\hline $\begin{array}{l}\text { Wells' shift in methods seems to reflect a shift in beliefs } \\
\text { based on interviews. She said she was on board with } \\
\text { disciplinary literacy at the beginning of the intervention, } \\
\text { but actions proved otherwise. Experience seemed to } \\
\text { change this. She began to use content area literacy } \\
\text { strategies (Frayer model, etc.) and adapt those } \\
\text { strategies to integrate disciplinary literacy by the end of } \\
\text { the intervention. Data indicate she was resistant to } \\
\text { content-area literacy at the beginning of intervention } \\
\text { (e.g., she mentioned workshops, PD, and filing cabinet } \\
\text { full of strategies, but she never used most of them), but } \\
\text { then her use of content-area literacy strategies and } \\
\text { interview data concerning those strategies by the end } \\
\text { of the intervention provides evidence that she started to } \\
\text { value them. (Also note that we did not verbally } \\
\text { encourage her to use any strategies outside of the } \\
\text { intervention.) Wells noted she had little time for } \\
\text { content-area literacy strategies, and she seemed to } \\
\text { value transmission methods at the beginning of the } \\
\text { intervention. Yet by the end of the intervention, time did } \\
\text { not seem to be an issue, and she became more } \\
\text { interested in disciplinary literacy as she watched her } \\
\text { students engage in it. }\end{array}$ & $\begin{array}{l}\text { Shift in beliefs } \\
\text { Shift in ideas and } \\
\text { practice concerning } \\
\text { content-area literacy } \\
\text { Experience observing } \\
\text { students } \\
\text { Conflict between } \\
\text { statements and } \\
\text { actions }\end{array}$ & $\begin{array}{l}\text { Shift in actions } \\
\text { and beliefs } \\
\text { Positive effects of } \\
\text { observation }\end{array}$ \\
\hline
\end{tabular}

\section{RESULTS}

According to Reinking and Watkins (2000), "the data reported in formative experiments represent a synthesis and interpretation of events, which may be organized in various ways" (p. 399). In this section we organize results by reporting several pedagogical assertions, focusing on the teacher, that emerged from the retrospective analysis. We illustrate these assertions and the data from which they were derived using illustrative key events (Patton, 2002) typically associated with modifications of the intervention and subsequent outcomes.

Assertion: A teacher's beliefs are foundational to aligning history instruction and literacy goals, but instantiating those beliefs in instruction is mediated by previous, imagined, and enacted practice.

It is well established that history teachers' beliefs about instruction are central in their decisions to integrate or not integrate particular methods into their classroom (Cochran-Smith \& Zeichner, 2005; Van Hover \& Yeager, 2003, 2007). Yet working with and observing Ms. Wells as she implemented the intervention revealed a more complex interaction 
between her beliefs about history instruction and her clear desire to more closely align her instruction with literacy goals. We termed that desire her imagined practice, which was grounded in her belief that closer alignment was necessary and important. But achieving her imagined practice was initially constrained by her previous instructional practice. However, that constraint was subsequently overridden when her enacted practice in the context of the intervention resulted in desirable outcomes consistent with the capabilities and perspectives she hoped to instill in her students through history instruction. The roots of this assertion emerged early in the intervention when she repeatedly deferred incorporating the graphic organizer into her instruction, as she had agreed to do during planning. Thus, her hesitation and reluctance to incorporate the graphic organizer into her instruction became an inhibiting factor that led to our first modification, as detailed in the subsequent section.

\section{Key Events Leading to Modification}

To begin instruction in the intervention during the first topical unit, Ms. Wells introduced a portion of the charter King Charles II granted to lord proprietors allowing them to claim the Carolinas. She had planned to use the graphic organizer, along with small group work, to structure students' reading, because the document was lengthy and contained language unfamiliar to most students. However, when we observed the lesson, instead of using the graphic organizer, she asked students to respond to a list of 14 questions that she had used in previous years. These questions focused primarily on finding explicit information in the text. Small-group work, which she had rarely used prior to the intervention, was part of planning for introducing strategy instruction, thus suggesting that at least part of the instructional plan was implemented. Yet students clearly struggled to read the text and answer the questions, and they responded negatively to the activity. For example, when Ms. Wells asked students about features of the charter, specifically its format, audience, language, and writing style, students expressed frustration. One student stated, "I don't understand most of the words in this document" (video, September 15,), while another noted, "I get what this thing means in general, but I have no idea what the charter really says because the words are too old" (video, September 15 ,). Archaic language was a concern for many of the students, and the length of the document seemed to overwhelm them.

After the lesson, Ms. Wells explained that for the previous five years she had used these questions occasionally with students in relation to reading historical texts. She rationalized that this deviation from the original plan to implement the graphic organizer was reasonable and in the best interest of 
the project and its goals, but her comments reinforced our emerging data and our interpretation that despite her declared enthusiasm for moving her instruction toward the new standards, she was reluctant to move away entirely from her established instructional approaches and practices. Some of the questions in the guide were consistent with the pedagogical goal, such as considering the author's background, but they mostly invited rote responses and did not scaffold students' comprehension or strategic analysis of the texts. Students' responses validated that interpretation in a subsequent lesson during which Ms. Wells again used the 14 questions. Again students responded with confusion and a lack of enthusiasm, as illustrated in this exchange between Kasey and Harold (video, September 15,):

Kasey: I don't get it. Are we supposed to read these questions in order or just try to find the answers somewhere in this [points to the charter document]?

Amber: I don't even know how you read this thing. It's too confusing.

Harold: Y'all just let me know when you get something because I can't do this.

Kasey: We'll just write something down. I'm sure she'll give us the answers tomorrow.

After the lesson, Ms. Wells again remarked that she had not introduced the graphic organizer and promised to do so in the following class, which was scheduled to initiate the second topical unit of study. She encouraged us to schedule a visit specifically to observe her introducing it. However, during that lesson she again did not implement it.

She continued to use the 14-question guide with a new primary source in a subsequent lesson, after again indicating that she would use the graphic organizer, and students continued to struggle with analysis using the guide. Students again expressed difficulty in reading the primary sources, and our data suggested that their disengagement from the 14-question guide appeared to reinforce Ms. Wells's reluctance to use the graphic organizer, which she now told us she thought might be too difficult. For example, she explained (a) that she did not believe students had successfully completed the primary source activity from the previous week, (b) that she wanted students to practice reading a primary source again before moving on to the activities we had planned, (c) that students' comprehension skills were not adequate, and, thus, (d) that they would not be engaged with the project. In an interview she stated: 
This is one thing [i.e., reading comprehension] that concerns me. I have multiple students who struggle with reading and I am beginning to worry that this project may be too hard for them. I think it might be good for them, but I'm worried that the [intervention] strategies are going to overwhelm them, like the primary source activity. They just seemed so discouraged, and I want them to enjoy studying history. (Interview, September 19, 2011)

Although she had not indicated these concerns in our meetings prior to the intervention, the importance of this dual concern for her students' success and for their enjoyment of history became more evident as a critical factor in enhancing or inhibiting the intervention as a means to move her instruction and students' learning toward our pedagogical goal. Thus, we examined our data explicitly to search for insights about possible explanations for Ms. Wells' reluctance to initiate the graphic organizer that might suggest appropriate modifications.

Our analysis revealed three overlapping concerns as possible explanations, which we probed further in analysis of the second topical unit for the sake of considering modification and of opening up deeper pedagogical understanding: (a) concern that her students were not yet capable of using the strategies, and thus her worry that students would not experience success; (b) hesitancy to let loose of previous instructional activities, especially those she deemed successful; and (c) a commitment to conventional instructional activities and goals related to standardized testing, involving rote learning of facts about history.

\section{Modification}

With a better understanding of her concerns based on our analysis, before the next lesson we developed and suggested a new approach to strategy instruction. Because we had frequently observed Ms. Wells using model examples, often from previous students, we proposed a model blog activity to incorporate into class instruction using sample blog posts that illustrated making connections with a text, questioning the author's purpose, and drawing conclusions based on evidence within the invented blog exchange. She seemed enthusiastic about this modification, and we worked with her to develop the model (see Appendix B) and determine how it might be integrated into her instruction. She said that she would use it the next day, again encouraging us to be present to observe the lesson.

For the lesson, Ms. Wells decided to display the model blog post on her interactive whiteboard, using it to highlight relevant features of the model blog post as students discussed them. Students seemed intrigued, and many asked whose blog posts were used in the model. Ms. Wells explained 
that she had created a model blog exchange based on the reading that they had already completed "to use to talk about critical thinking and blogging" (field notes, September 29). After reading the blog exchange, Ms. Wells paired students to complete the activity, which she told them illustrated "critical thinking," the term she continued to prefer. A class discussion followed, focusing on where students could identify elements of critical thinking illustrated in the model blog exchange, targeting text that displayed making connections, questioning the author or text, and drawing conclusions based on evidence.

\section{Outcome}

After the lesson we noted Ms. Wells's enthusiasm for the activity and how her students responded, and subsequently, in our retrospective analysis, how it represented a turning point in her investment in the intervention and in aligning her instruction with literacy goals. For example, after the lesson, Ms. Wells exclaimed enthusiastically, "They loved that activity. I can't wait to do that every week with them. I think it's going to help them really get into thinking critically" (Interview, September 29, 2011). In light of subsequent lessons and our retrospective analysis, her comments suggested that she was motivated by (a) the increased engagement of her students, (b) their success with the activity, and (c) observing them thinking critically about the historical texts they were reading.

Her comments to us as she began the third topical unit also suggested an increasing interest in, awareness of, and commitment to integrating instruction aligned with the new professional standards identified in the CCSS. In discussing the topic of this unit, she stated:

I think this project gives me an opportunity to integrate some actual voices from South Carolina history and events not in the textbook and lets students think critically about actual people and events in our history using the elements of literacy we've been working on, which may, you know, give way to critical discussion, not an avalanche of loose opinion where no one is really listening to each other. I think [students] can use the structure that we looked at last week in the model post to help guide considerate discussion. (Interview, October 5, 2011)

The latter part of this statement suggested that the model blogs-to which her students had responded favorably_-perhaps in conjunction with the clear connection to state standards, signaled an important transformation in her instruction, more closely aligning it with the new standards. 
Assertion: Aligning history instruction and literacy goals benefits from an activity such as blogging, which may catalyze successful enacted practice.

Having students write blogs commenting on the historical texts they were reading was the distinctive component of the intervention. Its main purpose was to extend and reinforce students' experience with reading and analyzing historical texts through an engaging and potentially motivating activity. Yet this component played a key role in Ms. Wells's engagement in the project and in how her history instruction became more aligned with literacy goals. The challenges and obstacles to implementing blogging and subsequent modifications to address them seemed to prompt Ms. Wells to reconsider her instruction in the intervention and catalyzed the success of the intervention, in part, through the modifications she made to instruction.

\section{Key Events Leading to Modifications}

During the first unit of analysis, students and parents reported that the My Big Campus network was either blocked or slow to respond on computers outside of the district network. Most notably, the school district's filters prevented student access from computers outside school, which hindered multiple students from blogging with their university partners outside of class as originally planned.

Further, during the second topical unit, we noted, as did Ms. Wells, that students' blog postings were more like journal entries with short, personal, or summative reactions rather than analytic, critical reflections consistent with our goal. For example, Rosalyn posted the following on her blog after reading the secondary source for this unit ("Affra Harleston Coming," Bodie, 1991):

I find it interesting that she still asked to go on the boat even though she didn't have much money. She looked wealthy, because of her appearance, but she was practically broke because her father got "laid off", I guess you could call it, after working for an unworthy man. I like the fact that she got buried next to her husband after she died. I would want it the same way. (blog post, September 21)

Although pre-service teachers attempted to offer support to prompt more critical analysis, our data indicated that when students persisted in writing essentially summative responses, the pre-service teachers' responses tended to acquiesce, shifting their focus as well to summative content. For example, Ellen, Rosalyn's blog partner, responded: 
Even though Affra did not have but four shillings (which is probably like you only having $\$ 1$ ), I thought it was remarkable that the captain still thought that she was a wealthier lady. It must have been quite a change of lifestyle for Affra to go from being a member of the upper class to being a servant. What did you think about the hint of a "love story" that was in this text? I was a little surprised to see that Affra married John Coming, the captain's mate. Coming knew that Affra did not have much money and had agreed to be a servant for two years just to pay for her trip to Carolina-and he waited for her to finish and then married her. I agree that it was nice that she was buried next to Coming when she died. (blog post, September 22)

Ellen's response did contain elements of historical empathy, which, as we previously noted, was included in our conception of disciplinary literacy, yet her response, like many of the pre-service teachers' responses, did not suggest how to critically consider the text and did not go much beyond a summary. We and Ms. Wells identified this tendency as an inhibiting factor, at least indirectly contributing to a lack of progress toward promoting "critical thinking." Although she initially believed that the model blogs implemented in the second topical unit, along with support from pre-service teachers, would aid students in better understanding how to write a reflective blog post and greeted the model blog posts enthusiastically, she believed that her students would need more support to understand the process of writing a reflective blog post. She observed:

Most [students] struggle with writing in my class. I think they need a highly scaffolded, maybe step-by-step, guide to posting and responding on their blogs. I think they might get the critical thinking elements out of the new [model blog] activity, but I don't think the writing styles will transfer without guided instruction. From what I've seen in the blog responses so far and their questions in class, I think they need to be more aware of their writing and learn to ask themselves specific questions as they write. This is something [the English Language Arts teacher] and I have been talking about. (Interview, October 5, 2011)

Thus, Ms. Wells agreed that it was necessary to modify the intervention to allow time for students to write blog responses in her scheduled classes and to better support students in critically reading and responding to historical texts via blogging. 


\section{Modifications}

The modification to allow students to blog during class was not difficult, because Ms. Wells routinely provided time for independent work during most class periods. Thus, she decided that she would set aside time in two classes each week for students to rotate in groups of 5-6 to the computer room across the hall, which had a full-time supervisor, where they could all post to their blogs and read their partners' responses. This activity typically occurred during the first 30-40 minutes of each 70-minute lesson.

The modification to support students in responding to historical texts via blogging was somewhat more complex as we collaborated with Ms. Wells to develop a more explicit guide aimed at helping students develop and write blog entries that would (a) critically consider the source of information and author bias, (b) promote connections between historical texts and other information, and (c) prompt conclusions about historical events based on textual evidence, which, as Ms. Wells pointed out, corresponded to the state standards in social studies, which suggested that the intervention was prompting her to consider explicit connections between her teaching and the professional standards. The guide, which she introduced to students on the first day of third unit, consisted of seven questions/prompts to consider when writing a response to a reading and two prompts for responding to their blog buddy (see Appendix C).

\section{Outcomes}

Because these modifications required Ms. Wells to become more involved in students' blogging, she became more interested in the content and process of students' blogging. Two outcomes were noted following these modifications. In our analysis, we first noted that Ms. Wells was beginning to initiate pedagogical analyses of the intervention and had become actively engaged in considering modifications based on that analysis. Our analysis also suggested that the intervention had begun to influence the larger context of her teaching, beyond the pedagogical goal, as she became interested in collaborating with other teachers, such as the language arts teacher, to support students' writing practices in history.

Indeed, the modification to provide students with questions and prompts to consider in reading and blog response seemed to improve the content of students' posts. The following blog post from Rosalyn after the introduction of the structured prompt stands in contrast to the one cited previously and posted before this modification:

When I read the text, the first thing that came to my mind, was about how people still, not necessarily African Americans, aren't 
treated right. Before I even read the text, I knew that slaves were taken against their will and they were bought and sold freely. I found it really interesting that in the social class, the field workers were at the bottom even though they workk [sic] the hardest! Would yu [sic] have agreed with their social class? (blog post, October 10)

Rosalyn's posting here is more substantive and analytical, commenting on themes of equality and social class, drawing connections between her prior knowledge about slavery and information in the text she had read. Ms. Wells enthusiastically noted this shift from more summative to reflective and analytical blog posts, which seemed to spark her interest in observing her students post blog responses and how they reacted to their blog buddies' responses, suggesting further investment in the intervention and a more analytical stance. She noted:

I've been really interested in the discussions that are taking place on the blogs, and I think some of the things the university students are asking my students to think about are really great. I'd like to see how they react when they read blog posts and maybe ask them about their reactions while they're writing on their blogs. (Interview, October 19, 2011)

Modifying the blogging activity to include the structured prompt was thus identified as an enhancing factor and likewise suggested further modifications to capitalize on its emerging benefits, to which we now turn.

\section{Further Modification and Outcomes}

Ms. Wells decided to again modify the blogging component of the intervention to become a whole-class weekly activity. The opportunity to directly observe her students' sustained, motivated engagement with blogging seemed to reinforce her enthusiasm for the intervention and the ability of her students to contend with its emphasis on analytical skills she had previously doubted her students capable of exercising. In an interview after observing a class she stated:

I knew they would be excited about blogging, but I didn't think their excitement would last this long. I was under the impression that technology would just be old news to them after a while since they see it every day. I'm really impressed by how they stayed engaged with the project and are even asking me if they can keep blogging about readings after you leave. (Interview, October 25, 2011)

During our initial planning with Ms. Wells, she seemed to view the preservice teacher blog buddies as an ancillary, supplemental aid to help her 
students read and analyze historical texts. Further, she was not as interested in the blogging activity per se, preferring to focus on in-class strategy instruction-which, ironically, she then avoided, at least initially. Thus, she decided during the planning phase that her role in the blog component would be limited. Her intention at that juncture was only to check the blog exchanges for accuracy and appropriateness. However, our data indicated that her views of the blogging activity shifted as she became more involved with and reflective about it, seeing its positive influence in promoting students' engagement and her goals for aligning history instruction and literacy goals. In an interview, she stated:

I'm also kind of surprised at myself for wanting to incorporate the blogging as a part of class time. I'll admit when you first approached me about the project, what sold me was that students would blog on their own time and I wouldn't have to worry about going to the computer lab. Now, I'm interested in seeing them at work in the lab, and I keep thinking of ways I can include technology in my class. (Interview, October 25, 2011)

Further, having increased opportunities to hear students' conversations related to their blog posts while they worked in the computer lab provided Ms. Wells with examples that carried over to discussions in her classroom. For example, in a video we recorded of a lesson, we saw Ms. Wells observe the following conversation between two students:

Siena: ... I didn't know about Eliza Lucas Pink-something [laughs] taught her slaves to read and educated them.

Maria: Yeah! I said that too. I didn't know women could read back then. My grandma said she had to teach herself to read and she [sic] not that old.

Siena: [Laughs] Your grandma is old. Uh, I don't know, Eliza was rich so I figured she could read. I just thought people would get killed if they taught a slave or were nice to them, you know? (video, October 27)

Subsequently, during this lesson, Ms. Wells told the class as they divided into small groups:

Maria and Siena had a great conversation about what they wrote to their blog buddies. They talked about if it was OK or not for plantation owners to educate their slaves. Use your notes to think about reasons why plantation owners may or may not educate slaves. Come up with three pros and three cons and organize 
them in a T-chart. Then choose someone to present your pros and cons to the class. (video, October 27)

This was the first instance we noted of Ms. Wells using the intervention as a springboard to activities uncharacteristic of the instruction we had observed in her class prior to the intervention. It suggested to us that her views of literacy and texts and how they might be integrated into her history instruction were shifting toward her imagined practice, perhaps laying the groundwork for more ambitious goals of disciplinary literacy, promoting the success of the intervention.

Assertion: Instantiating instruction that aligns history instruction and literacy goals is enhanced and extended when a teacher observes its positive effects on students in relation to achieving valued pedagogical goals.

This assertion emerged mainly in the fourth and fifth instructional units, when no substantive data-driven modifications to the intervention occurred. Instead, Ms. Wells extended and expanded the intervention independently, and we became increasingly passive observers. During the third instructional unit, Ms. Wells had expressed pleasant surprise that her students' blog posts indicated their capability to engage in what she conceptualized as "critical thinking," which clearly pleased her. Our retrospective analysis suggested that observing these positive effects enabled her to break from past practice, moving from imagined to enacted practice that more closely aligned her pedagogical goals for history and engagement with the literacy goals to which she was committed. Seeing her students' success, with the help of the model blog, became a springboard to further alignment through activities that she enthusiastically initiated on her own, thus suggesting a transformation of her instruction from assimilating new activities and goals into past practice to a more substantive accommodation leading to curricular and instructional change. Accompanying this increased alignment were unanticipated positive outcomes such as increased use and integration of technology into Ms. Wells' instruction.

\section{Unanticipated Positive Outcomes}

As Ms. Wells continued to use the model blog activity, she independently decided to implement the original strategy instruction developed during planning for the intervention, which she had deferred during multiple previous class periods. During a lesson in the third topical unit, she decided, without our prompting, to use one of the graphic organizers that she had repeatedly avoided implementing in the previous units. Before the day's lesson, she enthusiastically told us: 
They got so much out of the blog exchange activity last week, I'm going to do it again this week after their buddies respond to their posts using one of their exchanges. But, today I thought I'd use the graphic organizer with them to critically discuss texts. (Interview, October 6, 2011)

Thus, after Ms. Wells's repeated deferments, the strategy instruction component was now implemented, but only after the intervention was modified to include a model blog post, the success of which among students became evident in relation to her pedagogical goals. Data gathered in the lesson during which Ms. Wells first used the graphic organizer suggested that it was engaging students in more critical reading and reflection consistent with the "critical thinking" Ms. Wells sought to inspire in her students. We, too, noted students' more diligent reading for a purpose, followed by a deeper discussion that the guided questions and graphic organizer demanded and that was not typical of class discussion observed before the intervention or during the first two units of instruction. Students' success clearly increased her enthusiasm for and commitment to the intervention, and also prompted her to expand and more fully integrate it into her history instruction.

For example, she paired the graphic organizer with excerpts from an eyewitness account in a letter about the Stono Rebellion written by Governor William Bull to the Royal Council (observation, October 12). She assigned students to work in the same small groups she had formed to consider a primary source introduced at the beginning of the first instructional topic. In contrast to the difficulty they had exhibited previously, students were clearly more at ease with reading a primary source and more invested in determining its meaning and reacting substantively to it within its historical context. Standing in contrast to the awkward and relatively superficial discussion we and Ms. Wells had observed in the first unit, we recorded the following substantive exchange:

Harold: OK, so this is a letter by Governor Bull about the Stono Rebellion and he seems mad.

Kasey: Yeah, he's mad because the rebellion scared him and he's worried that more slaves will rebel and the white people will lose control.

Amber: I don't really understand what the word "discerned" means [pointing to the box in the organizer where students address any words they do not understand].

Kasey: I'll look it up. [She looks up the word in the dictionary.] It means to see or to recognize. OK, so he saw that there was going to be a rebellion, like Ms. Wells talked about earlier. 
Harold: Yeah, and the governor wanted to notify the Royal Council because he wanted to get the Indians [Native Americans] to help control the slaves.

Amber: And the French to help too.

Kasey: The French?

Harold: Yeah, they used to like us. You've seen The Patriot [reference to a popular film about the American Revolution], right? (video, October 6)

The influence of her students' unanticipated success seemed particularly reinforced by the increased engagement of previously disengaged students. For example, she commented specifically on a student who was usually less inclined to participate in activities during class:

I can't believe how involved Harold is in this activity. I can't get him to do anything most days. He's not just talking, either. He's actually doing the activity! This graphic organizer seems to be keeping them on task and talking about the assignment. I could do this [activity] again and again. (Interview, October 10, 2011)

She was also positively impressed that students who had typically struggled academically, often with low reading ability, were succeeding. That impression stands in contrast to the concerns she expressed during the first two units about many of her students' capabilities to succeed in the intervention. For example, during the fourth unit she commented on Kerry, whom she described as a struggling learner:

Kerry, in particular, has shown such motivation during these activities that I've never seen before. After giving him these guides [graphic organizer and note-making tool], he really does not hesitate to do work, and that was not the case before [the intervention]. This is giving me ideas about how to help students who struggle to read and still do what I was going to do in the first place [italics added for emphasis]. (Interview, October 12, 2011)

These successes not only increased her investment in the intervention, but also generated unanticipated positive outcomes, some of which related directly to literacy goals. For example, in addition to her comment about Kerry, our data suggested that Ms. Wells was moving away from a deficit stance, acquiring more confidence that all of her students, with the right support, could engage successfully with the intervention and with texts in a manner more consistent with her conceptions of disciplinary literacy. In the fourth and fifth units she became more positively and optimistically focused on engaging and supporting those students. 
We also observed that working in the computer lab inspired her to employ online activities that connected to and extended the intervention while incorporating literacy goals associated with conducting online searches for information. For example, during the fourth unit, she asked students to search multiple sources online to find information about colonists in South Carolina who played a significant role in the American Revolution, which she reported to us had not previously been part of her instructional plan for that unit. This activity entailed locating, reading, and corroborating online information, which are skills included in the new curricular standards (NCSS, 2013).

These unanticipated outcomes suggested that the intervention, mediated by the success of her students, was transforming Ms. Wells's instruction, more closely aligning it with literacy goals. Consistent with the frame we used for conducting this formative experiments, we gathered data specifically to determine whether such a transformation was occurring. That is, was the intervention simply being assimilated into existing instruction, or was it being more fully accommodated, for example by generating new ongoing activities dedicated to new pedagogical and curricular goals (Reinking \& Watkins, 2000)? In the data we collected during the fourth and fifth units and in our retrospective analysis we found evidence of the latter. Most prominently, Ms. Wells independently initiated additional activities that built on and extended the benefits she saw proceeding from the intervention and from her students' enthusiastic and successful response to it. For example, in the fourth and fifth units, she introduced her students to a note-making guide and a discussion web (see Appendix A; Alvermann et al., 2012), which represented alternative options for strategy instruction that we had discussed with her during our initial planning prior to the intervention. Although she had not mentioned these activities since the original planning meeting, she now initiated them independently without consulting with us or informing us in advance. She explained that she believed her students were "ready to begin to thinking critically on an independent level" and that she was pleased about the types of thinking the strategy instruction, such as the graphic organizer, seemed to prompt (Interview, October 12, 2011).

During the fourth topical unit, we also noted evidence that literacy was becoming more central to Ms. Wells's pedagogical perspectives. For example, we noted her increasing use of small-group activities and discussion centered on primary and secondary texts. In this unit, she had students read secondary texts recounting the perspectives of Daniel Axtell and Eliza Lucas Pinckney, two plantation managers. Then she divided the class into small groups (something she had stated before the intervention that she rarely did), asking each group to consider these texts while completing a 
discussion web, sharing their opinions with another group, and reporting conclusions to the class. Such activities were occupying more instructional time and replacing more conventional activities that we had observed before the intervention (e.g., taking lecture notes from her presentation on a screen using a digital projector and completing workbook activities). We also noted that she had abandoned any consideration or use of the 14-question guide that she had introduced as a link to her previous instruction.

Literacy became more integral to Ms. Wells's instruction. For example, she independently planned and implemented what she referred to as a "document walk." In that activity, she created several stations, each with a primary source document related to causes of the American Revolution. Students in small groups rotated to each station, with the task of deciding what cause each document suggested. She explained why she initiated this new activity by telling us, "I've had this activity since a workshop I did a few years ago, but I've never used it before" (Interview, November 4, 2011). Consistent with our analysis, her comment suggested that the intervention provided a new frame that allowed her to incorporate well-received, but unused, ideas about using texts to teach history in ways that promoted literacy goals consistent, in this instance, with the concept of disciplinary literacy.

In an interview at the end of the intervention phase, one of Ms. Wells's statements reflects her stance toward the intervention and literacy. It also reflects several key themes, findings, and recommendations we summarize from our retrospective analysis:

I feel like I've gotten to do so many things these past few months that I haven't done before with literacy in history. I used strategies I hadn't thought about in years because my students just responded so well to what we were doing with the project. It's been eye-opening because I used to just tell students what they didn't know, but now I'm finding ways to help them read and learn without so much of my help. And it's working in a lot of ways, I think. The struggling readers still struggle, but they're keeping up and that's encouraging. (Interview, November 9, 2011)

\section{DISCUSSION}

The assertions that emerged from our analysis comprise an emerging pedagogical theory that informs how middle-school social studies instruction might be transformed to align history instruction and literacy goals. That emerging theory can inform teacher educators; individuals providing inservice development; policymakers who wish to implement new curricular standards; practitioners who wish to reflect on and better understand 
their own practice; and researchers who wish to test, refine, and extend that theory by replicating this and similar interventions in other contexts.

Although the aims and practices of the intervention in this formative experiment, and in this instance the teacher's orientation, did not fully encapsulate the concept of disciplinary literacy, we believe our findings are relevant to promoting that conceptual frame and understanding how it might be instantiated in practice. Because the goals of the present investigation were less ambitious and modified freely to conform to the teacher's perspectives and goals, our findings suggest that transforming history instruction to be consistent with the tenets of disciplinary literacy may be particularly challenging and may need to be incremental. Reinforcing that conclusion is that Ms. Wells was an enthusiastic participant and committed broadly to perspectives and goals related to disciplinary literacy.

Specifically, the results of this investigation suggest that building bridges between past, imagined, and enacted practice is critical. However, our findings suggest that those bridges may be tenuous and fragile, requiring carefully constructed conditions for success. Ms. Wells clearly expressed her belief in the rationale for and goals of aligning her instruction with literacy goals. However, during the first two topical units she exhibited a selfconscious reluctance to move these goals fully into the mainstream of her instruction. Thus, alignment between history instruction and literacy goals may require a carefully selected and implemented intervention, ideally one that enables teachers to observe students' success in meeting goals, especially if success is observed in unexpected ways and among students who are academically challenged. In this investigation, the blogging component of the intervention catalyzed those conditions, but only when structured questions and prompts scaffolded students' reading and when they were provided with model blog posts. These, in turn, produced the success that enabled Ms. Wells to cross a threshold to transformative practice.

In retrospect, her hesitancy during the first two units seemed to reflect an internal struggle to let go of the familiar and to embrace the new, which was understandable given her previous years of successful teaching experience. Her decision to implement the 14-question guide in place of the graphic organizer also suggested that she was attempting to bridge that divide by relying on a familiar activity. She seemed to be trying to balance an implicit realization that a new focus on literacy was a broadly transformative pedagogical goal, and one that she valued, with preserving the more conventional instructional frames with which she was more familiar. Girard and Harris (2012) noted a similar trend in their observations of a high-school history teacher's integration of disciplinary literacy into an advanced-placement class, in that case supporting the complex relationship between history teachers' beliefs about and practice grounded 
in disciplinary literacy. Thus, it may be particularly important for pre- and in-service educators invested in preparing teachers to contend with the new standards to have a keen awareness of existing beliefs and involvement in past practice. Attention may need to focus on activities that reveal those beliefs and practices while comparing them to imagined practices and their implications for potential discomfort (Colwell, in press).

Our analysis suggested that a commitment to centering instruction on analyzing texts, which Ms. Wells clearly had at the outset of this study, may be more readily instantiated in instruction when a teacher observes students' capable, enthusiastic, and motivated engagement in activities consistent with that instructional orientation. However, this conclusion may cut in both directions. That is, if students are observed having difficulty or responding unenthusiastically, aligning history instruction and literacy goals may be inhibited. Teachers' perceptions of their students' reading and analytical abilities may, therefore, be an inhibiting factor that an intervention, when strategically implemented, may mitigate. More modestly, the intervention here may raise consciousness about the role of reading ability and the extent to which students have the capability to take a critically evaluative stance toward historical texts. That outcome may be important in light of the research suggesting that content-area teachers are typically not inclined to specifically address differing reading abilities or to consider it their responsibility (Hall, 2005; O'Brien et al., 1995; O'Brien \& Stewart, 1990; Siebert \& Draper, 2008). However, our results suggest that activities aimed at promoting literacy in history may need to be framed and implemented carefully so that they do not confirm a teacher's concerns about students' capability to engage in it. For example, careful selection of initial primary and secondary texts, explicit models and guides, smallgroup discussion framed to support less capable students, and engaging activities, such as blogging, that help students persist with difficult tasks may foster initial success that may in turn reinforce a teacher's investment in activities consistent with the new standards.

Our findings here also support Sturtevant and Linek's (2003) conclusion that initial success may be foundational to instantiating literacy as a driving force in content-area instruction and to compounding and sustaining its benefits toward transforming instruction. It suggests that increasing the odds of immediate success, perhaps through carefully designed and implemented interventions (Monteo-Santo et al., 2014), may be critical for shifting instruction toward the new standards, at least when teachers have a commitment, at least in principle, to the type of instruction those standards imply. Alternatively, it may be helpful to acknowledge and communicate to teachers that dynamic, perhaps thus steeling their resolve to persevere in the face of initially disappointing results. 
Less clear is how the conditions that led to more alignment might be created outside a formative experiment such as this one. Although we took steps to minimize the influence of this acknowledged limitation of our methodological approach (see Colwell \& Reinking, 2013), it is unreasonable to assume that our involvement had no influence on the process or on outcomes. For example, would Ms. Wells have persevered with the intervention beyond the first two units without any commitment to participating in a study and without any sense of obligation to cooperate with us? Would she have independently developed scaffolds to help her students read primary and secondary texts and then respond to them with critical reflection? Would she have crossed the threshold to transformative practice when only presented with a promising intervention? The answers to these questions await further research, which we believe will benefit from the results of the present study. Replication, which has been documented to be minimal in published education research (Makel \& Plucker, 2014), is essential to this methodological approach, because replication enables the development of more generalizable pedagogical theory (Reinking \& Bradley, 2008).

We believe our results also enrich the extensive literature documenting the intimate connection between teachers' beliefs and practice when teaching school subjects such as social studies and science (e.g., Adler, 1984; Chiodo \& Brown, 2007; Yore, 1991) and, more specifically, how literacy goals and perspectives might be integrated into those subjects (e.g., Hall, 2005; Shanahan \& Shanahan, 2008; Sturtevant \& Linek, 2003; Theriot \& Tice, 2009). Our findings illustrate the subtle interplay between teachers' beliefs and practices and their reciprocal influences on outcomes and pedagogical goals, which complexly interact to instigate changes in practice.

Finally, our data suggested that the blogging component of the intervention served its intent as a useful genre to inspire reflection (Shoffner, 2007), enhanced, in this instance, by responses from pre-service teachers. An unanticipated outcome was that when Ms. Wells became directly involved with the blogging, it also gave her a better understanding of how her students considered and responded to historical texts. When that occurred, students' blog postings frequently inspired her to incorporate them into class activities and discussions. Further, toward the end of the intervention, Ms. Wells used blog posts as a reference point and model for other in-class activities and discussions. Her students, too, would refer to them naturally and spontaneously in their small-group work. Consequently, she reconsidered the use of digital technology in her classroom, positioning it in a more central role in her curriculum to complement existing instruction. Our findings are consistent with other studies suggesting that incorporating the Internet into history instruction motivates adolescents to engage in analyzing historical texts (Bull et 
al., 2008; Hicks \& Doolittle, 2008; Martin \& Wineburg, 2008). Yet these results prompt further consideration of how online activities may inspire and support students' analytical practices in history and how exactly they might promote a closer alignment between history instruction and literacy goals.

\section{CONCLUSION}

The relation between literacy and the teaching of academic subjects such as history has shifted across many decades. Perspectives that have exerted influence on the thinking of the field, falling in and out of favor, include developmental approaches focused on remedial reading and writing (Bean \& Readence, 1989); the mantra that "every teacher is a teacher of reading," an investment in developing general content-area strategies and activities (Alvermann \& Moore, 1991; Moore, Readence, \& Rickelman, 1983); and, most recently, disciplinary literacy, with its focus on helping students acquire skills, strategies, and dispositions exercised among professionals in a discipline (Moje, 2007, 2008; Shanahan \& Shanahan, 2008).

What these perspectives all have in common is that, although they can claim some conceptual validity, they have not been widely adopted, and have sometimes been resisted, by content-area teachers. Consequently, they have had relatively little long-term influence on teaching in subject areas (Siebert \& Draper, 2008; Snow, 2002), leaving literacy goals as a valued but impotent stepchild in middle- and high-school subject areas. The likely reasons for that marginalized status have been identified in the literature for many years, often supported by empirical evidence. For example, O'Brien et al. (1995) argued that the dominant model of infusing content literacy into pre- and in-service teacher education had failed because it did not take into account the complexities of curriculum, pedagogy, and school culture. They called for more naturalistic studies that acknowledge such complexities and that have potential to reveal the deep pedagogical understandings necessary to infuse literacy into the teaching of academic subjects.

Our intent in the present investigation was to respond to that call, which we believe remains valid. Further, we believe that formative experiments provide a particularly useful methodological approach for seeking those deep pedagogical understandings that, in this case, might authentically align history instruction and literacy goals. Further, we believe that it is an opportune and auspicious time to renew attention to aligning history instruction with literacy goals, particularly in teacher education, given the impetus provided by the imperatives of new curricular and professional standards that reinforce such alignment. 


\section{REFERENCES}

Achugar, M., \& Carpenter, B.D. (2012). Developing disciplinary literacy in a multilingual history classroom. Linguistics and Education, 23, 262-276.

Adler, S. (1984). A field study of selected student teacher perspectives toward social studies. Theory and Research in Social Education, 12(1), 13-30.

Afflerbach, P. \& VanSledright, B. (2001). Hath! Doth! What? Middle graders reading innovative history text. Journal of Adolescent and Adult Literacy, 44(8), 696-707.

Alridge, D.P. (2006). The limits of master narratives in high school history textbooks: An analysis of representations of Martin Luther King, Jr. Teachers College Record, 108(4), 662-686.

Alvermann, D.E., Gillis, V.R., Phelps, S.F. (Eds.). (2012). Content area reading and literacy: Succeeding in today's diverse classrooms (7th ed.). Boston, MA: Allyn \& Bacon.

Alvermann, D.E., \& Moore, D.W. (1991). Secondary school reading. In R. Barr, M.L. Kamil, P.B. Mosenthal, \& P.D. Pearson (Eds.), Handbook of reading research (Vol. 2, pp. 951-983). White Plains, NY: Longman.

Bain, R.B. (2005). They thought the world was flat? Applying the principles of How People Learn in teaching high school history. In M.S. Donavan \& J.D. Bransford (Eds.), How students learn history in the classroom (pp.179-313). Washington, DC: The National Academy Press.

Bain, R.B. (2006). Rounding up unusual suspects: Facing the authority hidden in the history classroom. Teachers College Record, 108(10), 2080-2114.

Bain, R.B. (2012). Using disciplinary literacy to develop coherence in teacher education: The clinical rounds project. The History Teacher, 45(4), 513-532.

Barab, S., \& Squire, K. (2004). Design-based research: Putting a stake in the ground. The Journal of the Learning Sciences, 13(1), 1-14.

Barton, K.C. (1996). "I just kinda know": Elementary students' ideas about historical evidence. Theory and Research in Social Education, 25, 407-430.

Barton, K.C., \& Levstik, L.S. (2004). Teaching history for the common good. Mahwah, NJ: Lawrence Erlbaum Associates.

Bean, T.W., \& Readence, J.E. (1989). Content reading: Current state of the art. In D. Lapp, J. Flood, \& N. Farnan (Eds.), Content area reading and learning (pp. 14-23). Englewood Cliffs, NJ: Prentice Hall.

Beck, I.L., \& McKeown, M.G. (2001). Inviting students into the pursuit of meaning. Educational Psychology Review, 13(3), 225-241.

Beck, I.L., McKeown, M.G., Sandora, C., Kucan, L., \& Worth, J. (1996). Questioning the author: A yearlong classroom implementation to engage students with text. The Elementary School Journal, 96(4), 385-414.

Beyer, B.K (2008). How to teach thinking skills in social studies and history. The Social Studies, 99(5), 196-201.

Bodie, I. (1991). South Carolina women. Orangeburg, SC: Sandlapper Publishing.

Botstein, L. (1991). Damaged literacy: Illiteracies and American democracy. In S.R. Graubard (Ed.), Literacy: An overview by 14 experts (pp. 55-84). New York, NY: Hill \& Wang.

Bradley, B. A., \& Reinking, D. (2011). Revisiting the connection between research and practice using design research and formative experiments. In N. Duke \& M. Mallette (Eds.), Literacy research methodologies (2nd ed., pp. 188-212). New York, NY: Guilford Press.

Britt, M.A., \& Aglinskas, C. (2002). Improving students' ability to identify and use source information. Cognition and Instruction, 20(4), 485-522.

Brown, A.L. (1992). Design experiments: Theoretical and methodological challenges and creating complex interventions in classroom settings. The Journal of the Learning Sciences, 2(2), $141-178$.

Brozo, W.G., Moorman, G., Meyer, C., \& Stewart, T. (2013). Content area reading and disciplinary literacy: A case for the radical center. Journal of Adolescent and Adult Literacy, 56(5), 353-357. 
Bull, G., Hammond, T., \& Ferster, B. (2008). Developing Web 2.0 tools for support of historical inquiry in social studies. Computers in the Schools, 25(3-4), 275-287.

Chiodo, J.J., \& Brown, T.D. (2007). Student perceptions of teaching: Assessing their mental images of teaching social studies. Journal of Social Studies Research, 31(1), 12-26.

Cobb, P., Confrey, J., diSessa, A., Lehrer, R., \& Schauble, L. (2003). Design experiments in educational research. Educational Researcher, 32, 9-13.

Cochran-Smith, M., \& Zeichner, K.M. (2005). Executive summary: The report of the AERA panel on research and teacher education. In M. Cochran-Smith \& K.M. Zeichner (Eds.), Studying teacher education: The report of the AERA panel on research and teacher education (pp. 1-36). Washington, DC \& Mahwah, NJ: American Educational Research Association \& Lawrence Erlbaum Associates.

Cole, A. L. \& Knowles, J. G. (1993). Teacher development partnership research: A focus on methods and issues. American Educational Research Journal, 30(3), 473-495.

Coleman, D. (2011). Bringing the Common Core to life. Retrieved from http://usny.nysed.gov/ $\mathrm{rttt} /$ docs/bringingthecommoncoretolife/fulltranscript.pdf

Colwell, J. (2016). Examining pre-service teachers' beliefs about disciplinary literacy in history through a blog project. Action in Teacher Education, 38(1), 34-48.

Colwell, J., Hunt-Barron, S., \& Reinking, D. (2013). Obstacles to developing digital literacy on the Internet in middle-school science. Journal of Literacy Research, 45(3), 295-324.

Colwell, J., \& Reinking, D. (2013). Integrating disciplinary literacy into middle-school and preservice teacher education. In T. Plomp \& N. Nieveen (Eds.), Educational design researchPart B: Illustrative cases (pp. 469-480). Enschede, the Netherlands: SLO.

Corbin, J., \& Strauss, A. (2008). Basics of qualitative research (3rd ed.). Los Angeles, CA: Sage.

Creswell, J.W. (2007). Qualitative inquiry E research design: Choosing among five approaches. Thousand Oaks, CA: Sage.

Damico, J., Baildon, M., Exter, M., Guo, S. (2009/2010). Where we read from matters: Disciplinary Literacy in a ninth-grade social studies classroom. Journal of Adolescent $\mathcal{E}$ Adult Literacy, 53(4), 325-225.

De La Paz, S. (2005). Effects of historical reasoning instruction and writing strategy mastery in culturally and academically diverse middle school classrooms. Journal of Educational Psychology, 97(2), 139-156.

De La Paz, S., \& Felton, M. (2010). Reading and writing from multiple source documents in history: Effects of strategy instruction with low to average high school writers. Journal of Contemporary Educational Psychology, 35, 174-192.

Denzin, N.K. (1989). The research act (3rd ed.). Englewood Cliffs, NJ: Prentice Hall.

Design-Based Research Collective. (2003). Design-based research: An emerging paradigm for educational inquiry. Educational Researcher, 32(1), 5-8.

Doherty, C.A., \& Doherty, K.M. (2005). The thirteen colonies: South Carolina. New York, NY: Facts on File.

Draper, R.J. (2008). Redefining content-area literacy teacher education: Finding my voice through collaboration. Harvard Educational Review, 78(1), 60-83.

Draper, R.J., Broomhead, P., Jensen, A.P., \& Siebert, D. (2010). Aims and criteria for collaboration in content-area classrooms. In R.J. Draper (Ed.) \& P. Broomhead, A.P. Jensen, J.D. Nokes, \& D. Siebert (Co-Eds.), (Re)Imagining content-area literacy instruction (pp. 1-19). New York, NY: Teachers College Press.

Duffy, A.M. (2001). Balance, literacy acceleration, and responsive teaching in a summer school literacy program for elementary school struggling readers. Reading Research and Instruction, 40(2), 67-100.

Faggella-Luby, M.N., Graner, P.S., Deshler, D.D., \& Drew, S.V. (2012). Building a house on sand: Why disciplinary literacy is not sufficient to replace general strategies for adolescent learners who struggle. Top Language Disorders, 32(1), 69-84. 
Fang, Z., \& Pace, B.G. (2013). Teaching with challenging texts in the disciplines: Text complexity and close reading. Journal of Adolescent $\mathcal{E}$ Adult Literacy, 57(2), 104-108.

Fehn, B., \& Koeppen, K.E. (1998). Intensive document-based instruction in a social studies methods course and student teachers' attitudes and practice in subsequent field experiences. Theory E Research in Social Education, 26(4), 461-484.

Geertz, C. (1977). The interpretation of cultures. New York, NY: Basic Books.

Girard, B., \& Harris, L.A. (2012). Striving for disciplinary literacy instruction: Cognitive tools in a world history course. Theory E Research in Social Education, 40, 230-259.

Glaser, B., \& Strauss, A. (1967). The discovery of grounded theory. Chicago, IL: Aldine.

Gravemeijer, K., \& Cobb, P. (2006). Design research from a learning design perspective. In J. van den Akker, K. Gravemeijer, S. McKenney, \& N. Nieveen (Eds.), Educational design research (pp. 17-51). New York, NY: Routledge.

Guthrie, J., \& Wigfield, A. (2000). Engagment and motivation in reading. In M. Kamil, P. Mosenthal, P. Pearson, \& R. Barr (Eds.). Handbook of reading research (Vol. III, pp. 545-561). Mahwah, NJ: Erlbaum.

Hall, L.A. (2005). Teachers and content area reading: Attitudes, beliefs, and change. Teaching and Teacher Education, 21, 403-414.

Hicks, D. (2005). Continuity and constraint: Case studies of becoming a teacher of history in England and the U.S.A. International Journal of Social Education, 20(1), 18-51.

Hicks, D., \& Doolittle, P.E. (2008). Fostering analysis in historical inquiry through multimedia embedded scaffolding. Theory and Research in Social Education, 36(3), 206-232.

Hinchman, K.A., \& Moore, D.W. (2013). Close reading: A cautionary interpretation. Journal of Adolescent \& Adult Literacy, 56(6), 441-450.

Hotchkiss, K., \& Hougen, M. (2012). Writing like a historian: What teacher candidates should know and be able to teach. The Social Studies, 103(4), 149-157.

Hynd, C.R. (1999). Teaching students to think critically using multiple texts in history. Journal of Adolescent and Adult Literacy, 42, 428-436.

Hynd-Shanahan, C. (2013). What does it take?: The challenge of disciplinary literacy. Journal of Adolescent \& Adult Literacy, 57(2), 93-98.

Ivey, G., \& Broaddus, K. (2007). A formative experiment investigating literacy engagement among adolescent Latina/o students beginning to read, write, and speak English. Reading Research Quarterly, 42, 512-545.

Lee, C.D., \& Spratley, A. (2010). Reading in the disciplines: The challenges of adolescent literacy. New York, NY: Carnegie Corporation of New York.

Makel, M.C., \& Plucker, J.A. (2014). Facts are more important than novelty: Replication in the education sciences. Educational Researcher, 43(6), 304-316.

Martin, D., \& Wineburg, S. (2008). Seeing thinking on the web. The History Teacher, 41(3), 305-319.

McKenney, S., Nieveen, N., \& van den Akker, J. (2006). Design research from a curriculum perspective. In J. van den Akker, K. Gravemeijer, S. McKenney, \& N. Nienke (Eds.), Educational design research (pp. 67-90). London, England and New York, NY: Routledge.

McKenney, S., \& Reeves, T.C. (2012). Conducting educational design research. New York, NY: Routledge.

Moje, E.B. (2007). Developing socially just subject-matter instruction: A review of the literature on disciplinary literacy teaching. Review of Research in Education, 31, 1-44.

Moje, E.B. (2008). Foregrounding the disciplines in secondary literacy teaching and learning: A call for change. Journal of Adolescent $\mathcal{E}$ Adult Literacy, 52(2), 96-107.

Monteo-Santo, C., De La Paz, S., \& Felton, M. (2014). Implementing a disciplinary literacy curriculum for U.S. history: Learning from expert middle school teachers in diverse classrooms. Journal of Curriculum Studies, 46(4), 540-575. 
Moore, D.W., Readence, J.E., \& Rickelman, R.J. (1983). An historical exploration of content area reading instruction. Reading Research Quarterly, 18, 419-483.

Mosborg, S. (2002). Speaking of history: How do adolescents use their knowledge of history in reading the daily news? Cognition and Instruction, 20, 323-358.

National Council for the Social Studies. (2013). The College, Career, and Civic Life (C3) Framework for Social Studies Standards: Guidance for Enhancing the Rigor of K-12 Civics, Economics, Geography, and History. Silver Springs, MD: NCSS.

National Governors Association Center for Best Practices \& Council of Chief State School Officers. (2010). Common Core State Standards Initiative. Retrieved from http://www. corestandards.org/

NCSS Task Force on Revitalizing Citizenship Education (2001). Creating effective citizens. Retrieved from www.socialstudies.org/positions/effectivecitizens

Neumann, D. (2013). Viewing history teaching: Balancing competing intellectual challenges. Social Education, 74(4), 184-188.

Nokes, J.D. (2008). Aligning literacy practices in secondary history classes with research on learning. Middle Grades Research Journal, 3(3), 29-55.

Nokes, J.D. (2010). Preparing novice history teachers to meet students' literacy needs. Reading Psychology, 31, 493-523.

Nokes, J.D. (2011). Recognizing and addressing the barriers to adolescents' "reading like historians." The History Teacher, 44(3), 379-404.

Nokes, J.D., Dole, J.A., \& Hacker, D.J. (2007). Teaching high school students to use heuristics while reading historical texts. Journal of Educational Psychology, 99(3), 492-504.

O'Brien, D.G., \& Stewart, R.A. (1990). Preservice teachers' perspectives on why every teacher is not a teacher of reading: A qualitative analysis. Journal of Reading Behavior, 22, 101-127.

O'Brien, D. G., Stewart, R. A., \& Moje, E. B. (1995). Why content literacy is difficult to infuse into the secondary school: Complexities of curriculum, pedagogy, and school culture. Reading Research Quarterly, 30(3), 442-463.

Parker, W. C., Lo, J., Yeo, A. J., Valencia, S. W., Nguyen, D., Abbot, R. D. . . Vye, N. (2013). Beyond breadth-speed-test: Toward deeper knowing and engagement in an advanced placement course. American Educational Research Journal, 50(6), 1424-1459.

Patton, M.Q. (1990). Qualitative evaluation and research methods (2nd ed.). Newbury Park, CA: Sage.

Patton, M. Q. (2002). Qualitative research and evaluation methods (3rd ed.). Thousand Oaks, CA: Sage.

Paxton, R.J. (1999). A deafening silence: History textbooks and students who read them. Review of Educational Research, 69(3), 315-339.

Reinking, D., \& Bradley, B.A. (2008). Formative and design experiments: Approaches to language and literacy research. New York, NY: Teachers College Press.

Reinking, D., \& Watkins, J. (2000). A formative experiment investigating the use of multimedia book reviews to increase elementary students' independent reading. Reading Research Quarterly, 35(3), 384-419.

Reisman, A. (2012). Reading like a historian: A document-based history curriculum intervention in urban high schools. Cognition E Instruction, 30(1), 86-112.

Rouet, J.F, Favart, M., Britt, M.A., \& Perfetti, C.A. (1997). Studying and using multiple documents in history: Effects of discipline expertise. Cognition \& Instruction, 15, 85-106.

Shanahan, T., \& Shanahan, C. (2008). Teaching disciplinary literacy to adolescents: Rethinking content-area literacy. Harvard Educational Review, 78(1), 40-61.

Shanahan, T., \& Shanahan, C. (2012). What is disciplinary literacy and why does it matter? Top Language Disorders, 32(1), 7-18.

Shoffner, M. (2007). Preservice English teachers and technology: A consideration of weblogs for the English classroom. Contemporary Issues in Technology and Teacher Education, 7(4), 245-255. 
Siebert, D., \& Draper, R.J. (2008). Why content-area literacy messages do not speak to mathematics teachers: A critical content analysis. Literacy Research and Instruction, 47, 229-245.

Snow, C.E. (2002). Reading for understanding: Toward an R \& D program in reading comprehension. Santa Monica, CA: RAND Reading Study Group.

Southern, E. (Ed.). (2009). Voices of the American Revolution in the Carolinas. Winston-Salem, NC: John F. Blair, Publisher.

Stahl, S.A., Hynd, C.R., Britton, B.K., McNish, M.M., \& Bosquet, D. (1996). What happens when students read multiple source documents in history? Reading Research Quarterly, 31(4), 430-456.

Stahl, S.A., \& Shanahan, C. (2004). Learning to think like a historian: Disciplinary knowledge through critical analysis of multiple documents. In T.L. Jetton \& J.A. Dole (Eds.), Adolescent literacy research and practice (pp. 94-115). New York, NY: Guilford Press.

Sturtevant, E.G., \& Linek, W.M. (2003). The instructional beliefs and decisions of middle and secondary teachers who successfully blend literacy and content. Reading Research and Instruction, 43(1), 74-89.

Sweeny, S.M. (2010). Writing for the Instant Messaging and text messaging generation: Using new literacies to support writing instruction. Journal of Adolescent $\mathcal{E}$ Adult Literacy, 54(2), 121-130.

Theriot, S., \& Tice, K.C. (2009). Teachers' knowledge development and change: Untangling beliefs and practices. Literacy Research and Instruction, 48, 65-75.

Van den Akker, J., Gravemeijer, K., McKenney, S., \& Nieveen, N. (Eds.). (2006). Educational design research. London, England, and New York, NY: Routledge.

Van Hover, S., \& Yeager, E. (2007). "I want to use my subject matter to . . .": The role of purpose in one U.S. secondary history teacher's instructional decision making. Canadian Journal of Education, 30(3), 670-690.

Van Hover, S., \& Yeager, E. (2003). "Making students better people?": A case study of a beginning history teacher. The International Social Studies Forum, 3(1), 219-232.

VanSledright, B.A. (2002a). Confronting history's interpretive paradox while teaching fifth graders to investigate the past. American Educational Research Journal, 39(4), 1089-1115.

VanSledright, B.A. (2002b). Fifth graders investigating history in the classroom: Results from a researcher-practitioner design experiment. The Elementary School Journal, 103(2), 131-160.

Weiler, G. (2003). Using weblogs in the classroom. English Journal, 92(5), 73-75.

Wineburg,S. (2001). Historical thinking and other unnatural acts. Philadelphia, PA: Temple University Press.

Wineburg, S.S. (1991). Historical problem solving: A study of the cognitive processes used in the evaluation of documentary and pictorial evidence. Journal of Educational Psychology, $83(1), 73-87$.

Yin, R. (2009). Case study research: Design and methods (4th ed.). Thousand Oaks, CA: Sage.

Yore, L. (1991). Secondary science teachers' attitudes toward and beliefs about science reading and science textbooks. Journal of Research in Science Teaching, 28(1), 55-72. 


\section{APPENDIX A}

\section{GRAPHIC ORGANIZERS FOR EXPLICIT ACTIVITY INSTRUCTION}

\section{STRUCTURED READING GRAPHIC ORGANIZER}

\begin{tabular}{|c|c|c|}
\hline $\begin{array}{l}\text { Think } \\
\text { about }\end{array}$ & Questions I can ask myself & Thoughts/Explanations \\
\hline $\begin{array}{l}\text { Author's } \\
\text { message }\end{array}$ & $\begin{array}{l}\text { What is the author trying tell me? Is the } \\
\text { author's message biased? }\end{array}$ & \\
\hline $\begin{array}{l}\text { Author's } \\
\text { clarity }\end{array}$ & $\begin{array}{l}\text { Is there anything in the text that I don't } \\
\text { understand? Does the author's choice of } \\
\text { words make sense to me? }\end{array}$ & \\
\hline $\begin{array}{l}\text { Author's } \\
\text { reasons }\end{array}$ & $\begin{array}{l}\text { Why is the author telling me this } \\
\text { information? What is the purpose of this } \\
\text { text? }\end{array}$ & \\
\hline $\begin{array}{r}\text { Think } \\
\text { about }\end{array}$ & Ask myself & Thoughts/Explanations \\
\hline Links & $\begin{array}{l}\text { What did I think about when I read the } \\
\text { text? What prior knowledge can I connect } \\
\text { to the text? }\end{array}$ & \\
\hline $\begin{array}{l}\text { Broken or } \\
\text { missing } \\
\text { links }\end{array}$ & $\begin{array}{l}\text { What do I still want to know about? What } \\
\text { do I wonder after finishing the reading? }\end{array}$ & \\
\hline Extension & $\begin{array}{l}\text { What can I do to find out more about what } \\
\text { I'm still wondering? }\end{array}$ & \\
\hline \multicolumn{3}{|c|}{ Negotiations/Conclusions } \\
\hline \multicolumn{3}{|c|}{$\begin{array}{l}\text { Now that l've thought about the text from the author's perspective and my own, what conclusions can I } \\
\text { draw? What are my reactions? }\end{array}$} \\
\hline
\end{tabular}

\section{NOTE-MAKING GRAPHIC ORGANIZER}

\begin{tabular}{l|l|}
\hline Before Reading-Brainstorm & Notes \\
\hline What do I already know about what I've read in this & \\
text? \\
What do I already know about this topic? & \\
\hline During Reading-Gather information & \\
\hline What does the author directly or specifically tell me in & \\
this text? & \\
\hline After Reading-Infer & \\
\hline How does the information I knew before reading & \\
connect to the information I learned during reading (or, \\
does it)? \\
Can I draw any personal connections to this text? If so, \\
what? \\
What inferences can I make? \\
Do my inferences agree with or disagree with what I \\
already knew? \\
What do I still wonder after reading this text?
\end{tabular}




\section{DISCUSSION WEB GRAPHIC ORGANIZER}

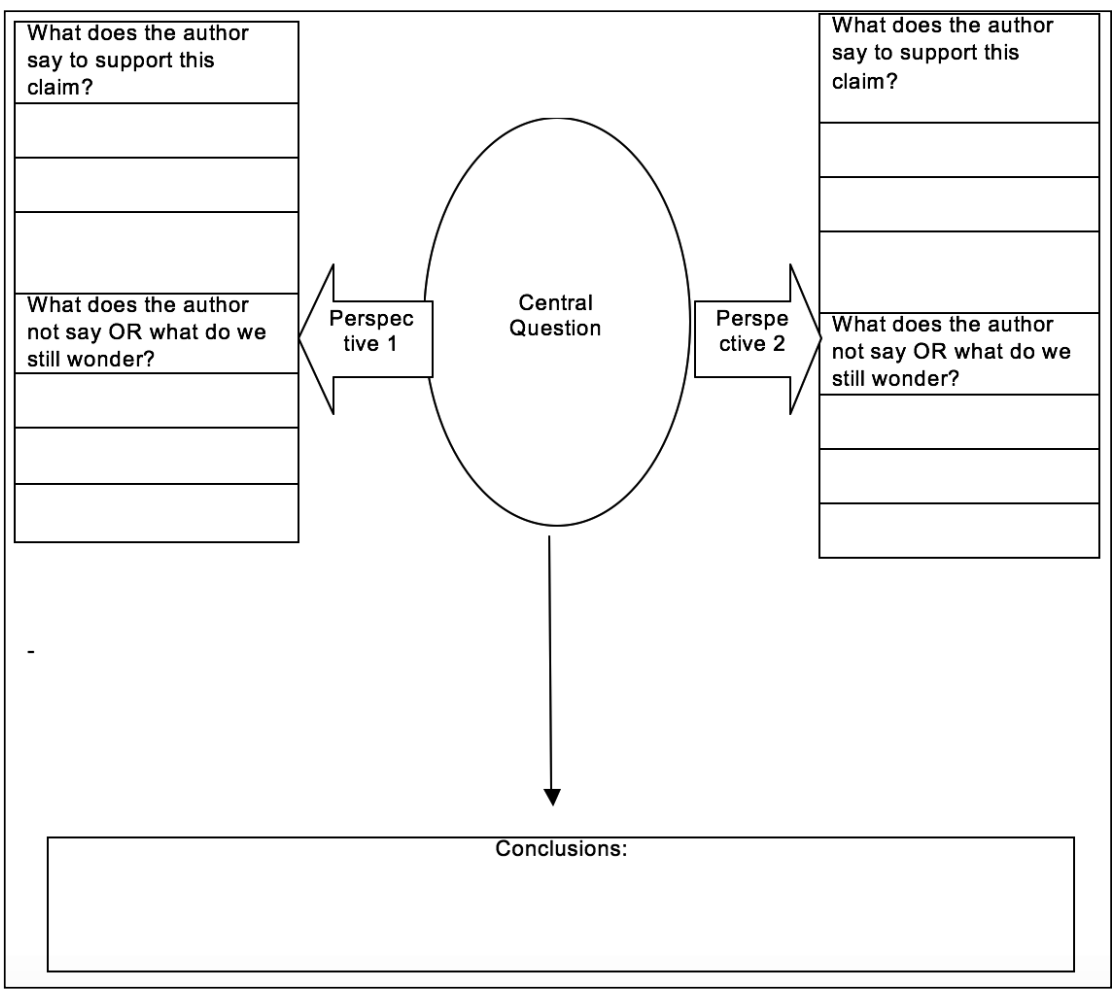




\section{APPENDIX B}

\section{MODEL BLOG ACTIVITY}

\section{MODEL RESPONSE POST}

\section{8th-Grade Student Response to "Affra Harleston Coming":}

Hey!! How's it going? Did you see the Clemson game Saturday? Awesome!! Ok, so when I read about Affra I wondered why she was important to South Carolina history and what made her so special to be included in a book about South Carolina Women. I THINK the author wanted me to understand how difficult it must have been for people to come over to South Carolina from Ireland because Affra was very poor and was just looking for SOMETHING better than where she was from. I'm not sure if the text is biased or not, but I think the author definitely wants you to feel sorry for Affra by the way she describes her as penniless and worried about her brother, Charles. All I could think about was how I would feel if I had to get on a boat with no money and no idea of what the place I was going to was really like. I would be scared silly! It kind of makes me think about the people who come to America now to escape wherever they are from and to make money and how they must be really scared too. I liked the reading, but I guess I still wonder (or was surprised) that they would give a lady 100 acres of land. Were women allowed to have land back then??? Later!

Blog Buddy Response:

Hi! Yes, how 'bout them TIGERS!!! I was at the game and it was crazy! Anyway, I really enjoyed reading your response to the Affra passage. I, too, think it must have been incredibly difficult to just leave the country I was from and where my family was to go to another country that you had never been before. Also, did you catch where the captain determined Affra was "lady born"? That means that Affra was from an upper class in society, probably nobility and was probably not used to living in poor conditions, much less working in servitude. What do you think that was like for Affra? I also agree with you that the author wants us to feel sorry for Affra, but I think she also wants us to really understand the differences between the rich life that Affra was used to living and the poor, servant-like life she was now entering in Carolina. I'm like you-I would have been scared silly as well to do what Affra did! That was a great connection you made when you thought about current immigrants coming to America. They must also feel scared and sad to leave their homes. Since America no longer offers people land in return for a few years of work, why is it still appealing to move to America? Do you think today's immigrants are as fortunate as the 
ones like Affra? I'm not certain that women could own land back then by themselves, but maybe they could own it under the watch of their sponsor (who Affra ended up marrying!) You should look on the Internet or ask your teacher for more information about women owning land in the 1600s in Carolina. That brings me to the thing I wondered more about-wasn't this a love story? Where were the details? Why did the author leave out that information? Any ideas? Those were the things I was curious about after reading. Great job with your response!

\section{8th-Grade Student Response:}

I did notice "lady born" but I didn't know what it meant so I kind of skipped over it-oops, I guess I missed some important info there J Thanks for helping me out! I think since Affra was so used to being rich, it must have been TERRIBLE to work like a servant. I mean I'm not rich but I don't even like doing chores or yard work with my dad. I hate yard work! I can't imagine doing that for a few years straight. I think that people like to move to America even though we're not giving away land anymore because we do have a lot of freedom that other countries don't have. I mean, women can do a lot here that they can't in other places. Yeah, I'm not too interested in the love story but I will ask my teacher about women owning land back then. Talk to ya soon!

\section{MODEL RESPONSE ACTIVITY}

1. Underline text where the buddies talk about what the author wanted them to learn from the text.

2. Circle text where the buddies discuss bias.

3. Place a star by text where the buddies talk about what they thought about when they read the text.

4. Draw two lines under text where the buddies made connections to other similar topics.

5. Strike through text where the buddies talked about what interested them.

6. Draw a box around text where the buddies discussed what they still wondered.

7. Lightly shade text where the buddies answered each others' questions.

8. Draw a smiley face next to text where the buddies reacted to each others' opinions. 


\section{APPENDIX C \\ REFLECTIVE BLOG WRITING GUIDE}

WRITING A BLOG RESPONSE

Read the text carefully. Write an $8-10$ sentence blog response by considering the following questions:

1. What is the author trying to tell me or what do you think the author wants you to learn from this text?

2. Is the text biased? In other words, does it sound like the author includes their opinions in the text?

3. Explain why you think the text is biased.

4. What did you think about when you read the text? (For example, did you think about any current events, the news, movies, or books you may have read?)

5. What do you already know about this topic that you can connect to this text?

6. What interested you about this text?

7. What do you still wonder about after finishing the reading?

RESPONDING TO YOUR BLOG BUDDY'S POSTS

Read your buddy's response post carefully. Write an 8-10 sentence blog response by:

1. Thoughtfully answering the questions that your buddy asked you in their post.

2. Reading your buddy's opinions about the text and reacting to their opinions. (For example, if they said they agreed with or were interested in a certain part of the text, tell them your opinion about that part of the text.) 
JAMIE COLWELL is an assistant professor of literacy at Old Dominion University. Her research interests include disciplinary literacy and digital literacy using qualitative and design-based research methods. Dr. Colwell has recently published in these areas in the Journal of Literacy Research and the Journal of Adolescent and Adult Literacy.

DAVID REINKING is the Eugene T. Moore Professor of Education at Clemson University. His scholarship focuses on understanding literacy and literacy instruction in relation to the affordances, demands, and social influences of digital communication. In classrooms, he employs design-based research to study how instructional interventions can authentically achieve valued pedagogical goals related to literacy. He has served as co-editor of Reading Research Quarterly and editor of the Journal of Literacy Research. 